\title{
Iron-Overload, Oxidative DNA Damage and Differential Transcript Expression of Iron Homeostasis Genes in Human Cortical Cataracts
}

\author{
Sankaranarayanan Rajkumar ${ }^{1,2 *}$, Nair Gopinathan Vidya ${ }^{1}$, Darshini Ankit Ganatra ${ }^{3}$ and Abhay \\ Raghukant Vasavada $a^{1,2,3,4}$
}

${ }^{1}$ Department of Molecular Genetics and Biochemistry, Iladevi Cataract and IOL Research Centre, India

${ }^{2}$ Genetics Unit, Aditya Jyot Foundation for Twinkling Little Eyes, India

${ }^{3}$ Department of Cell and Molecular Biology, Iladevi Cataract and IOL Research Centre, India

${ }^{4}$ Raghudeep Eye Hospital Gurukul Road, India

*Corresponding author: Dr. Sankaranarayanan Rajkumar, M.Sc., Ph.D., Genetics Unit, Aditya Jyot Foundation For Twinkling Little Eyes, Plot No.153, Road No. 9, Major Parameshwaran Road, Opp. S.I.W.S. College, Wadala (West), Mumbai-400031, Maharashtra, India, Tel: +91-8511262859

\begin{abstract}
Purpose: The purpose of the study is to determine the level of iron, its role in oxidative damage and to profile and measure the level of transcript expression of genes responsible for iron homeostasis in lenses of human cataracts.

Materials and methods: Human whole lenses (WLs) were obtained from donors' eyes $(n=33)$ within 8 hours of death. A total of 167 (control, $n=35$ and cataract, $n=132$ ) anterior central capsules (ACC) harboring lens epithelial cells (LECs) and lens aspirate containing LECs, primary and secondary lens fiber cells (LFCs) were collected postoperatively. Control samples were obtained mainly from patients suffered from lenticular trauma or subjected for myopic corrections. Lenticular total iron was determined by Atomic Absorption Spectrophotometer (AAS). Comet assay using lens epithelial cells was performed to determine the oxidative DNA damages. Quantitative real-time polymerase chain reaction (qRT-PCR) was performed to profile and determine the level of transcript expression of genes of iron homeostasis in lenses. An in vitro culture model using fetal human lens epithelial cell line (FHL124) was used to validate the effect of iron on oxidative DNA damage and expression of iron homeostasis genes.
\end{abstract}

Results: Cortical cataract (CC) had significantly higher levels of iron $(58.89 \pm 20.56 \mu \mathrm{g} / \mathrm{g}$ dry tissue weight, $\mathrm{p}=0.00)$ than control lenses $(17.82 \pm 5.29 \mu \mathrm{g} / \mathrm{g}$ dry tissue weight) and revealed a significant increase in tail length $(\mu)(79.59$ \pm 21.31 vs. control, $66.56 \pm 15.68 ; p=0.005)$ and olive moment ( $29.69 \pm 10.31$ vs. control, $26.97 \pm 8.12, p=0.018)$ by Comet assay in LECs. Fetal human lens epithelial cell line (FHL124) treated with $500 \mu \mathrm{M}$ (concentration equivalent to lenticular iron level in $\mathrm{CC}$ ) of ferric chloride $\left(\mathrm{FeCl}_{3}\right)$, revealed a significant increase in tail length $(\mu)(80.71 \pm 8.63 \mathrm{vs}$. control, $62.55 \pm 6.63 ; p=0.01)$, tail DNA (\%) (44.01 \pm 18.02 vs. control $27.39 \pm 5.14 ; p=0.05)$, tail moment (36.87 \pm 17.33 vs. control, $18.1 \pm 3.41 ; p=0.02)$ and olive moment $(27.41 \pm 6.72$ vs. control, $18.88 \pm 2.86 ; p=0.02$ ) suggestive of substantial DNA damage. QRT-PCR analysis displayed elevated level of iron responsive element (IRE) containing DMT1 (IRE-DMT1, 1.99 \pm 0.34 fold change to control, $p=0.046$ ) and diminished level of $F T H(0.13 \pm 0.02$-fold change to control; $p=0.01)$ in lenses of CC. However, in vitro model, though displayed a conflicting data as compare to human samples, exhibited a conventional coordinated regulation of iron within the system.

Conclusion: In conclusion, differential transcript expression of genes responsible for iron uptake (IRE-DMT1) and storage $(F T H)$ might lead to an increase in iron over-load in human lenses. Iron-over load could potentially accelerate the cascade of mechanisms leading to oxidative damage, as evident by increased level of DNA damage in cortical cataract and also in FHL124 cells treated with $\mathrm{FeCl}_{3}$.

\section{Keywords}

Lens, Iron, DNA damage, COMET Assay, Iron regulatory genes, Cortical cataract, Nuclear cataract, Subcapsular cataract

\section{Introduction}

The lens of the human eye is highly vulnerable to oxidative damage although it is well-protected from direct

Citation: Rajkumar S, Vidya NG, Ganatra DA, Vasavada AR (2018) Iron-Overload, Oxidative DNA Damage and Differential Transcript Expression of Iron Homeostasis Genes in Human Cortical Cataracts. Int J Ophthalmol Clin Res 5:091. doi.org/10.23937/2378-346X/1410091

Accepted: September 08, 2018: Published: September 10, 2018

Copyright: (c) 2018 Rajkumar S, et al. This is an open-access article distributed under the terms of the Creative Commons Attribution License, which permits unrestricted use, distribution, and reproduction in any medium, provided the original author and source are credited. 
oxygen supply [1]. Due to excessive oxidative stress, the lens undergoes several molecular changes including proteins [2], membranes [3], and deoxyribonucleic acid (DNA) [4] culminating in opacification or loss of transparency [5-9]. The opacification that occurs in any part of or in an entire lens, termed as cataract, obscures the passage of light through the lens [10]. Today this painless loss of vision is one of the leading causes of treatable blindness in the world [11]. Although treatable, cataract brings an enormous socio-economic burden for developed as well as developing countries. There are about 35.1 million cases of bilateral cataract reported worldwide with approximately $50 \%$ of the cases originating in Africa and Asia $[12,13]$. Surgical intervention is the only available treatment at present.

Iron is indispensable for life. Most organisms require iron to act as a metal cofactor for many enzymes and proteins involved in central cellular processes such as mitochondrial oxidation, respiration, DNA synthesis, oxygen transport and nitrogen fixation [14,15]. Maintenance of cellular iron homeostasis is accomplished by the coordinated regulation of iron uptake (DMT1, TFR1/2), storage (FTH, FTL), export (FPN) and regulatory (IRP1, IRP2, FBXL5) proteins. In enterocytes, dietary non-heme ferric ion is reduced by membrane bound ferrireductases and absorbed by the divalent metal transporter 1 (DMT1). The absorbed iron is then exported to blood circulation by the baso-lateral exporter, ferroportin (FPN) upon oxidation by membrane-bound multicopper oxidase hephaestin enabling it to bind to plasma transferrin (Tf) to form di-ferric Tf (Tf-Fe (III)). Diferric Tf is the major form of iron that binds to the cell surface transferrin receptors $1 / 2$ (TFR1/2) [16] of most of the cells followed by internalization of the Tf-Fe (III)-TFR1/2 complex by clathrin-mediated endocytosis. On acidification of the endosome, ferric iron is released from Tf, reduced by metalloreductase, and exported into the cytosol by DMT1. In the cytosol, the free iron is utilized for diverse physiological processes and the excess is bound to ferritin heavy (FTH) or light chains (FTL). However, the fate and cellular homeostasis of iron is determined by iron regulatory proteins 1 and 2 (IRP1 and IRP2) [17]. Iron regulatory proteins are cytosolic proteins that regulate the post-transcriptional expression of several iron homeostasis gene encoding proteins involved in iron uptake, sequestration, and export, upon binding to their iron-responsive elements (IREs) within the $5^{\prime}$ or $3^{\prime}$ un-translated regions (UTRs). The storage and export of iron in and out of cells are accomplished by the coordinated regulation of IRP1 and IRP2 proteins [17]. In the iron deficient condition, IRPs bind to 5' IREs in FTH/FTL and FPN mRNAs with high affinity to repress translation, and to $3^{\prime}$ IREs in DMT1 and TFR1/2 mRNAs to block its degradation. However, when cellular iron is in excess, IRPs do not bind to IREs, promote synthesis of $F T H / F T L$ and FPN, and assist the degradation of DMT1 and TFR1/2 mRNA. Further, IRPs lose their RNA binding capacity either through conformational changes resulting from the enhanced Fe-S cluster assembly within IRP1 or enhanced proteasomal degradation of IRP2. Selective degradation of IRP2 is preceded by its iron-dependent polyubiquitination via a Skp1/Cul1/ Rbx1 (SCF) E3 ubiquitin ligase complex containing FBXL5 [18-21]. FBXL5 exhibits iron-sensing properties, as it is stabilized in the presence of iron and oxygen by forming a Fe-O-Fe center within its $\mathrm{N}$-terminal hemerythrin-like domain. Loss of this center in iron-starved and/ or hypoxic cells exposes a degron via a conformational change $[22,23]$. This allows proteasomal degradation of FBXL5, which leads to concomitant accumulation of IRP2. Thus, the coordinated regulation of iron by IRPs ensures that cells acquire adequate iron for their needs without reaching toxic levels $[17,18]$. Despite its inevitable role in many biologically important processes, iron invokes considerable oxidative stress and promotes deleterious irreversible damage to the cells when the coordinated regulation of iron homeostasis is perturbed [24]. Iron undergoes Fenton reaction, in which the ferrous form of it $\left(\mathrm{Fe}^{2+}\right)$ is oxidized into its ferric form $\left(\mathrm{Fe}^{3+}\right)$ by hydrogen peroxide $\left(\mathrm{H}_{2} \mathrm{O}_{2}\right)$ and generates a hydroxyl ion $\left(\mathrm{OH}^{-}\right)$and the dangerous hydroxyl radical $(\mathrm{OH})$. The $\mathrm{OH}$ is very reactive and can cause oxidative damage to DNA, proteins and lipids. In fact, the $\mathrm{Fe}^{2+}$ is absorbed into the body from the diet and is not entirely excreted except through menstruation, shedding of dead skin cells, and bleeding due to trauma. Therefore, the total tissue iron levels build up with age [25]. High iron stores and deviations from its normal physiological concentration were noticed in diseases such as cardiomyopathy, liver cirrhosis, diabetes mellitus, neurodegeneration, and cancer [26-28]. Lens siderosis, a clinical condition characterized by deposition of iron molecules in lens tissue usually caused by retention of an iron-containing intraocular foreign body, has also been reported to cause cataract [29-33]. Iron-induced oxidative damage was also reported in eye diseases [34,35] including cataract [36], age-related macular degeneration [37], diabetic retinopathy [38], vitreoretinal diseases [39], optic neuritis, optic neuropathy, glaucoma, and retinal degeneration [25]. However, reports associating lenticular iron-overload with the regulation of iron homeostasis and oxidative DNA damage in cataract development are scanty.

Hence, the present study was designed to address the association of iron in oxidative DNA damage in cataract development and to provide insights into the expression of transcripts of genes responsible for iron homeostasis. The quantity of lenticular total iron, level of transcript expression of iron homeostasis genes (DMT1, $F B X L 5, F P N, F T H, F T L, I R P 1, I R P 2$ and TFR2), and degree of DNA damage upon iron supplementation were analyzed to establish an association of iron with cataractogenesis using human cataract lenses as well as an in vitro FHL124 cell line models. 


\section{Materials and Methods}

\section{Clinical examination and selection of patients}

The study adhered to the tenets of the Declaration of Helsinki for research involving human tissues and was approved by the ICIRC-Institutional Ethics Committee (IEC/ICIRC/2012-V15). A written informed consent was obtained from the patients ( $>40$ years of age). The type of cataract was examined preoperatively using slit-lamp biomicroscopy (Carl Zeiss, Oberkochen, Germany) by a trained ophthalmologist. The modified lens opacification classification system III (LOCS III) [40] was used to determine the type and grade of cataract. Lenses with grade 3 opacification for all cataract types (nuclear, cortical and posterior subcapsular) were only included in the study. Patients with a history of glaucoma, retinitis pigmentosa, diabetes, retinal detachment, uveitis, vitreous hemorrhage, steroid medication, and any ocular surgery were excluded from the study.

\section{Collection of samples}

Human whole lenses (WLs) were obtained from donors' eyes $(n=33$ ) within 8 hours of death from Red Cross Society (Ahmedabad, Gujarat, India). Lenses were dissected from the enucleated eye, transferred to the sterile phosphate buffered saline (PBS), $\mathrm{pH} 7.4$, and examined under an operating microscope (Carl Zeiss, Oberkochen, Germany) to detect the presence of any opacity. Lenses without any form of opacity (clear) were used as controls ( $n=5)$, and lenses exhibiting opacity ( $n=28$ ) in any portion were classified accordingly as cortical cataract (CC, $n=12$ ), nuclear cataract (NC, $n=$ 11 ) and subcapsular cataract (SC, $n=5)$. The WLs were maintained as it is for iron determination and stored at $-80{ }^{\circ} \mathrm{C}$ until further use.

A total of 167 (control, $n=35$ and cataract, $n=132$ ) anterior central capsules (ACC) harboring lens epithelial cells (LECS) and lens aspirate containing LECs, primary and secondary lens fiber cells (LFCs) were collected postoperatively from Raghudeep Eye Hospital, Ahmedabad, Gujarat, India. Control samples were obtained mainly from patients suffered from lenticular trauma or subjected for myopic corrections. Through a clear corneal incision ( $3 \mathrm{~mm}$ in length), a continuous curvilinear capsulorhexis (CCC) procedure was performed under local anesthesia ( $2 \%$ xylocaine) and the ACC of 3-5 mm in diameter was removed with viscoexpression. The ACC harboring LECS were collected using forceps to avoid direct damage to the LECs and were either transferred to PBS for comet assay (control, $n=10$; cataract, $n=26$ ), or added to corresponding lens aspirates (control, $n=25$; cataract, $n=$ 106). Lens aspirate containing LECs and LFCs was transferred to sterile conical centrifugal tubes (BD Biosciences, MD, USA) and centrifuged at $3000 \mathrm{~g}$ for $10 \mathrm{~min}$ at 4 ${ }^{\circ} \mathrm{C}$. The supernatant was decanted, and the pellet was washed twice with PBS and added with $1 \mathrm{ml}$ of TriZol reagent for RNA isolation and stored at $-20^{\circ} \mathrm{C}$ until use.

\section{Determination of lenticular iron by Atomic Ab- sorption Spectrophotometer (AAS)}

The level of iron in lenses was determined by the previously described method [41]. Briefly, lenses were collected in acid-washed amber glass vials and dried under reduced pressure at $37{ }^{\circ} \mathrm{C}$ in a hot air oven for the first one hour followed by drying overnight at $60^{\circ} \mathrm{C}$ for approximately 16 hours. The dry weight of each lens was measured, digested in a mix of $5 \mathrm{ml}$ of nitric acid: perchloric acid (3:1) in a closed chamber until the solid particle was no longer visible. The digested contents were pre-heated at $100{ }^{\circ} \mathrm{C}$ in a microwave oven for an hour and then at $200{ }^{\circ} \mathrm{C}$ till the acid contents became colorless and reduced to $2-3 \mathrm{ml}$. Then the content was allowed to cool, mixed with the required volume of distilled water, filtered through a Whatman No. 42 filter paper, and made up to $50 \mathrm{ml}$ with HPLC grade distilled water. The quantity of total iron was determined using Spectra AA220 Zeeman flame atomic absorption spectrophotometer (Varian Australia Pty Ltd., Mulgrave, Australia) and expressed as micrograms per gram tissue dry weight.

\section{In vitro analysis using human lens epithelial cell culture and iron supplementation}

Fetal Human Lens Epithelial cell line (FHL124) generated from human capsule-epithelial explants [42] was a kind gift from Prof. John Reddan. The human origin of it was authenticated using short tandem repeat (STR) profiling and reported in our previous study [43]. FHL124 cells exhibited $99.5 \%$ homology with native human LECs. Further, it was found to show expression of LEC specific and phenotypic markers such as FoxE3, alpha-A-crystallin and pax6 [44]. FHL124 cells from the 15th passage was grown in $1.5 \mathrm{ml}$ of Eagle's minimal essential media (MEM) (Sigma, St.Louis, USA) with 10\% fetal bovine serum (FBS) (HiMedia, Mumbai, India) in a six-well plate with an initial seeding of $75 \times 103$ cells/well. Cells were maintained at $35{ }^{\circ} \mathrm{C}$ and $5 \% \mathrm{CO}_{2}$ until confluence, and then they were serum starved for 24 hours. Cells were divided into two groups: control group and treatment group. In the treatment group, the growth medium was supplemented with 150, 250 and $500 \mu \mathrm{M}$ (i.e. 25, 50 and $75 \mu \mathrm{g}$ per $\mathrm{ml}$, respectively) of $\mathrm{FeCl}_{3}$ (Sigma-Aldrich, Bangalore, India). Treatment was continued for 24 hours, and the morphology as well as growth rate of cells were observed. Cells were harvested in $1.5 \mathrm{ml}$ of cold PBS after three washes followed by centrifugation at $2000 \mathrm{~g}$ for $30 \mathrm{~min}$ at $4{ }^{\circ} \mathrm{C}$. The cells were collected in $1 \mathrm{ml}$ of PBS and $200 \mu$ l of TriZol reagent (Invitrogen Inc, CA, USA) respectively for Comet assay and RNA extraction.

\section{Total RNA extraction and first strand cDNA synthesis}

Total RNA was isolated using Trizol reagent as per the manufacturer's instructions with little modification. Samples were homogenized using a motor driven tissue grinder (Genetix Biotech Asia Pvt Ltd, New Delhi, India) 
fitted with a sterile RNAse free disposable micro-pestle (Himedia, Mumbai, India). The homogenate was incubated at room temperature for 5 minutes, added to $1 / 5$ volume of chloroform, vortexed for 30 seconds, and then kept on ice $\left(4{ }^{\circ} \mathrm{C}\right)$ for 10 minutes. The upper aqueous phase was separated by centrifugation (BioFuge, Heraeus, Germany) at $14,000 \mathrm{~g}$ for 15 minutes. The total RNA was pelleted by the addition of equal volume of cold isopropanol and subsequent centrifugation at $14,000 \mathrm{~g}$ for 15 minutes. The RNA pellet was washed using $75 \%$ ethanol, centrifuged at $8000 \mathrm{~g}$ for 10 minutes, and the air-dried pellet was dissolved in $30 \mu$ of diethyl pyrocarbonate (DEPC) (Sigma-Aldrich, Bangalore, India) treated water. The quantity of total RNA was determined by obtaining optical density at $260 \mathrm{~nm}$ and its purity was assessed by estimating the ratio of absorbance at 260/280 nm using a UV-Vis Spectrophotometer (Lambda 25, Perkin-Elmer, USA). First strand cDNA synthesis was carried out in a $20 \mu \mathrm{l}$ reaction volume containing $1 \mu \mathrm{g}$ Oligo dT(18) (New England Biolabs, Hitchin, UK), $0.5 \mu \mathrm{g}$ Random Hexamer (N6) (New England Biolabs, Hitchin, UK), $1 \mathrm{mM}$ dNTPs, (Thermo Fisher Scientific Inc., Waltham, MA, USA), 40U human placental RNase inhibitor (New England Biolabs, Hitchin, UK), and $200 \mathrm{U}$ M-MuLV Reverse transcriptase (New England Biolabs, Hitchin, UK) in $1 \mathrm{XRT}$ reaction buffer $\left(7.5 \mathrm{mM} \mathrm{KCl}, 0.3 \mathrm{mM} \mathrm{MgCl}_{2}, 0.1\right.$ $\mathrm{mM}$ DTT) for every $1 \mu \mathrm{g}$ of total RNA. The primers were allowed to anneal with RNA at $70^{\circ} \mathrm{C} / 5$ minutes and the contents were cooled immediately on ice. The reverse transcription step was carried out at $25^{\circ} \mathrm{C} / 5$ minutes, followed by $42{ }^{\circ} \mathrm{C} / 60$ minutes, and $70^{\circ} \mathrm{C} / 15$ minutes. All the thermal steps were performed in a thermal cycler, DICE TP600, (Takara, Shiga, Japan). The synthesized cDNA samples were stored at $-20^{\circ} \mathrm{C}$.

\section{Analysis of expression level of iron regulatory genes by quantitative real-time PCR (QRT-PCR)}

Quantitative real-time PCR was carried out in a $20 \mu \mathrm{l}$ reaction volume containing $10 \mu \mathrm{I} 2 \mathrm{X}$ QRT SYBR mix I (Takara, Shiga, Japan), $10 \mathrm{ng}$ CDNA, and $10 \mathrm{pM}$ each of forward and reverse primers. Amplification was performed in a LightCycler 480II (Roche Diagnostics GmbH, Mannheim, Germany) with the following thermal cycles; one cycle of pre-incubation at $95{ }^{\circ} \mathrm{C}$ for $1 \mathrm{~min}$, followed by 50 cycles of amplification at $95{ }^{\circ} \mathrm{C} / 10 \mathrm{sec}, 50-60{ }^{\circ} \mathrm{C} / 10$ $\mathrm{sec}$, and $72^{\circ} \mathrm{C} / 10 \mathrm{sec}$. A melting curve program was also performed to confirm the specificity of the products, and agarose gel electrophoresis was performed to verify the presence and size of the amplicons. For normalization of level of target gene expression (non-IRE and IRE form of DMT1, FBXL5, FPN, FTH, FTL, IRP1, IRP2 and $T F R 2$ ), cumulative mean $\mathrm{Cp}$ value of four housekeeping genes (ACTB, GAPDH, 18SrRNA and 28SrRNA) were used as reference. The fold change in expression of each target genes was determined utilizing efficiency corrected calculation models by the formula; ratio $=\left(\mathrm{E}_{\text {target }}\right)^{\Delta{ }^{\Delta p}}{ }_{\text {target }}$

Table 1: List of qRT-PCR and sequencing primers of target and reference genes.

\begin{tabular}{|c|c|c|c|c|}
\hline GENE & Direction & Sequence (5'-3') & Tm & Amplicon size (bp) \\
\hline & & Real-time qRT-PCR primers & & \\
\hline & & House-keeping genes & & \\
\hline \multirow[t]{2}{*}{ 18SrRNA } & FW & GGCGCCCCCTCGATGCTCTTAG & 62 & 89 \\
\hline & RV & GCTCGGGCCTGCTTTGAACACTCT & 61 & \\
\hline \multirow[t]{2}{*}{ 28SrRNA } & FW & TGTCGGCTCTTCCTATCATTGT & 53 & 81 \\
\hline & RV & ACCCAGCTCACGTTCCCTATTA & 55 & \\
\hline \multirow[t]{2}{*}{ ACTB } & FW & GTTGTCGACGACGAGCG & 52 & 93 \\
\hline & RV & GCACAGAGCCTCGCCTT & 52 & \\
\hline \multirow[t]{3}{*}{ GAPDH } & FW & TTGAGGTCAATGAAGGGGTC & 52 & 117 \\
\hline & RV & GAAGGTGAAGGTCGGAGTCA & 54 & \\
\hline & & Target genes & & \\
\hline \multirow[t]{2}{*}{ DMT1-NIRE } & FW & TCCCCATGATCTCCAGAAAC & 52 & 115 \\
\hline & RV & GGTTGCGGAGCTGGTAAG & 53 & \\
\hline \multirow[t]{2}{*}{ DMT1-IRE } & FW & TGCACCATGAGGAAGAAGCA & 52 & 134 \\
\hline & RV & ACACTGTCATCTGACATCTTCTGT & 57 & \\
\hline \multirow[t]{2}{*}{ TFR2 } & FW & AATGTCCTGAGTCAGAGCGG & 56 & 141 \\
\hline & RV & GGCAGACTCTACTGGAGCGA & 56 & \\
\hline \multirow[t]{2}{*}{ FPN } & FW & ATGGGGGCTAAGATGTTGGT & 52 & 108 \\
\hline & RV & CCAAAGGGATTGGATTGTTG & 50 & \\
\hline \multirow[t]{2}{*}{ FTH } & FW & TGGTTCTGCAGCTTCATCAG & 52 & 148 \\
\hline & RV & TGGAGCTCTACGCCTCCTAC & 56 & \\
\hline \multirow[t]{2}{*}{ FTL } & FW & GCCTGGTTCAGCTTTTTCTC & 52 & 145 \\
\hline & RV & GCTACGAGCGTCTCCTGAAG & 56 & \\
\hline \multirow[t]{2}{*}{ IRP1 } & FW & CAATGGCTCAGCAAGGTGT & 51 & 108 \\
\hline & RV & CTGCTTGGGTCAGGTTCG & 53 & \\
\hline \multirow[t]{2}{*}{ IRP2 } & FW & AGCTTCCAACAAGACCCGTA & 52 & 130 \\
\hline & RV & AGCAGGATACGCCTTTGAGT & 52 & \\
\hline \multirow[t]{2}{*}{ FBXL5 } & FW & AAGGTGCTCCAAATAAGGCA & 50 & 119 \\
\hline & RV & CTGATCAAGAGACTGGACGTG & 54 & \\
\hline
\end{tabular}


(control-sample) $/\left(\mathrm{E}_{\text {ref }}\right) \Delta \mathrm{cp}_{\text {ref(control-sample) }}$ [45]. Primer sequences, annealing temperatures and the size of the amplicons for all the target and house-keeping genes are given in Table 1.

\section{Evaluation of DNA damage by COMET Assay}

COMET assay was performed to evaluate the DNA damage by adopting the method proposed elsewhere [46] with slight modifications [47]. Before preparation for the comet assay, LEC viability was checked using the tryphan blue exclusion test [48]. Cell suspension of the LECs was prepared using mechanical tapping of ACCLECs (in $50 \mu$ l of PBS), by mild vortexing, for $20 \mathrm{~min}$ at $4{ }^{\circ} \mathrm{C}$ to shed LECs from the lens capsule. After this, the capsule was checked for the presence of adherent cells by PureBlu Hoechst 33342 nuclear staining dye as per the manufacturer's instruction (Bio-Rad, USA). Cell suspension of FHL124 cell lines was prepared by harvesting and washing thrice with PBS and suspended in $50 \mu \mathrm{l}$ of PBS. All precautions were taken to protect the cells from photo-oxidative damage.

Pre-coated slides were prepared as described elsewhere $[46,49]$. The LECs or FHL124 cell suspension was mixed with $75 \mu$ of $0.5 \%$ low melting point agarose prepared in $1 \mathrm{X}$ PBS was and layered onto the pre-coated slides and allowed to solidify at $4{ }^{\circ} \mathrm{C}$ for 1 minute. Slides were incubated in lysis solution $(1.25 \mathrm{mM} \mathrm{NaCl}, 0.01 \%$ $\mathrm{N}$-lauroyl sarcosine, $50 \mathrm{mM}$ EDTA, $100 \mathrm{mM}$ Tris, $\mathrm{pH}$ 10) for 1 hour at $4{ }^{\circ} \mathrm{C}$ to lyse the cells, and then incubated in electrophoresis buffer $(300 \mathrm{mM} \mathrm{NaOH}, 1 \mathrm{mM}$ EDTA, $0.2 \%$ DMSO, $0.01 \%$ hydroxyquinoline) for 20 minutes to unwind the strands prior to the run. Electrophoresis was carried out at $12 \mathrm{~V} / 150 \mathrm{~mA}$ for 20 minutes, slides were washed thrice with $0.4 \mathrm{M}$ Tris buffer, stained with 50 $\mu \mathrm{l}$ staining solution (0.25 $\mu \mathrm{M}$ Yo-Pro, $5 \%$ DMSO and $5 \%$ Sucrose) and examined using a fluorescent microscope (Carl Zeiss, Oberkochen, Germany) under 40X objective with blue light excitation. Individual comet images were captured with a cool charge-coupled device (CCD) camera attached to a microscope. About 50 cells or comets were scored for each sample. The degree of DNA damage was assessed with OpenComet software using various parameters such as tail length, percentage of DNA in the tail, tail moment, Olive moment, etc. [50]. Olive tail moment is defined as the product of the tail length and the fraction of total DNA in the tail and the formula to calculate olive tail moment $=$ (Tail.mean - Head.mean) $X$ Tail\%DNA/100. Tail moment incorporates a measure of both the smallest detectable size of migrating DNA (reflected in the comet tail length) and the number of relaxed/broken pieces (represented by the intensity of DNA in the tail) and the formula to calculate extent tail moment $=$ tail length $\times$ Tail\%DNA/100. Values of all parameters were expressed as mean \pm S.E. of median.

\section{Statistical analysis}

The level of iron in lenses was expressed as mean \pm SD microgram per gram tissue dry weight, the level of gene expression as mean \pm S.E. fold change to control, and the level of DNA damage as mean of medians \pm S.E. (micron $(\mu)$, percentage (\%), and arbitrary units) for all parameters. The student t-test was used to analyze the level of significance between the two groups. A one-way ANOVA test was used to compare the levels of significance between more than two groups. A $p$-value of less than 0.05 was considered significant.

\section{Results}

\section{Demographic details of subjects recruited for the study}

Source of samples, details of subjects, age, gender distribution, and different types of cataracts were described in Table 2. There was no difference in mean age between controls and cases of donors, while there was a significant difference in mean age of subjects with nuclear $(p=0.01)$ and posterior subcapsular cataract $(p=$ 0.02 ) compared to control subjects in patients.

\section{High level of iron in human cortical cataract lenses}

The level of total iron was determined in whole lenses of control and different types of cataract using atomic absorption spectrophotometry (Figure 1 and Table 3 ). Lenses with cataract showed a higher level of total iron as compared to clear lenses. Among lenses with different types of cataract, cortical cataracts (CC) exhibited the highest level of iron content $(58.9 \pm 20.6, p=0.001)$,

Table 2: Demographic details of subjects recruited for the study.

\begin{tabular}{|c|c|c|c|c|c|}
\hline \multirow{2}{*}{ Source } & \multirow{2}{*}{ Subjects } & \multirow{2}{*}{ n } & \multirow{2}{*}{ F/M } & Mean age \pm S.D. & \multirow{3}{*}{$\mathbf{P}$} \\
\hline & & & & (in years) & \\
\hline \multirow[t]{5}{*}{ Donor eyes } & Control & 5 & $2 / 3$ & $63.2 \pm 9.2$ & \\
\hline & Cataract cases & 28 & $13 / 15$ & $60.5 \pm 13.3$ & 0.66 \\
\hline & Cortical cataract & 11 & $7 / 4$ & $54.1 \pm 10.7$ & 0.12 \\
\hline & Nuclear cataract & 12 & $3 / 9$ & $65.2 \pm 16.2$ & 0.8 \\
\hline & Subcapsular cataract & 5 & $3 / 2$ & $63.2 \pm 2.5$ & 1 \\
\hline \multirow[t]{5}{*}{ Patients } & Control & 35 & $12 / 23$ & $58.4 \pm 10.2$ & \\
\hline & Cataract cases & 132 & $51 / 55$ & $60.1 \pm 10.4$ & 0.45 \\
\hline & Cortical cataract & 42 & $24 / 18$ & $61.1 \pm 10.6$ & 0.33 \\
\hline & Nuclear cataract & 59 & $26 / 33$ & $64.4 \pm 8.5$ & 0.01 \\
\hline & Posterior subcapsular cataract & 31 & $14 / 17$ & $50.2 \pm 6.7$ & 0.02 \\
\hline
\end{tabular}

$\mathrm{N}$ : Number of samples, F: Female, M: Male, S.D.: Standard Deviation. 


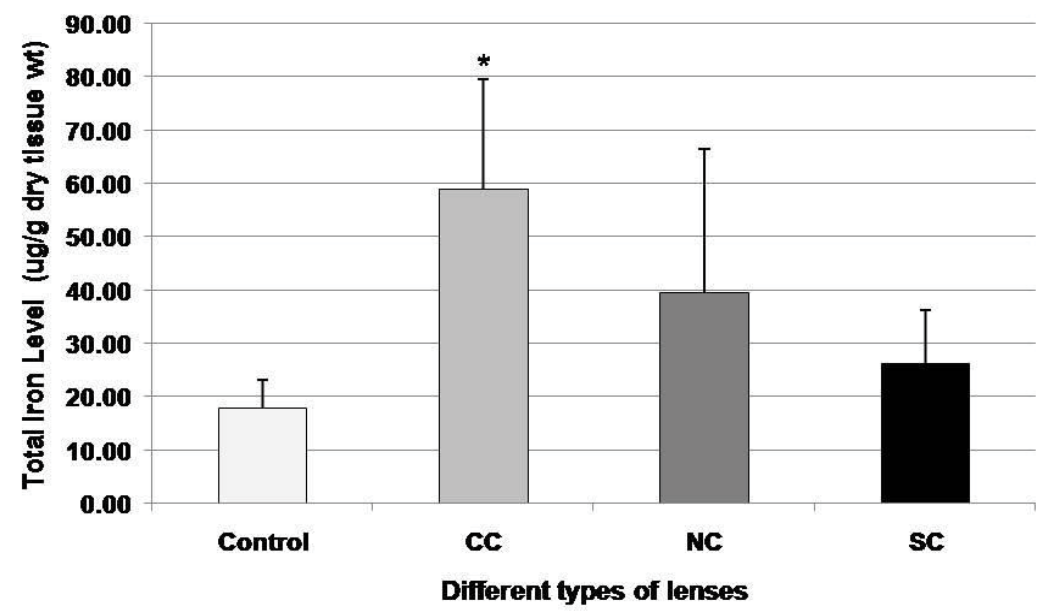

Figure 1: Determination of level of iron in different types of cataracts.

Level of iron was determined by atomic absorption spectrophotometry (AAS) in different types of lenses obtained from cadaveric human donor eye; Control, $(n=5)$, CC: cortical cataract, $(n=12)$, NC: nuclear cataract, $(n=11)$, and SC: subcapsular cataract, $(n=5)$. Values are expressed as mean \pm S.D. and "indicates $p<0.001$ (Student's t-test).

Table 3: Determination of Lenticular Iron.

\begin{tabular}{|c|c|c|}
\hline \multirow[b]{2}{*}{ Type of lenses (n) } & \multicolumn{2}{|c|}{$\begin{array}{l}\text { Level of iron ( } \mu \mathrm{g} / \mathrm{g} \text { tissue } \\
\text { weight) }\end{array}$} \\
\hline & Mean \pm S.D. & p \\
\hline Control (5) & $17.82 \pm 5.29$ & \\
\hline Cortical Cataract (11) & $58.89 \pm 20.56$ & 0.00 \\
\hline Nuclear Cataract (12) & $39.42 \pm 27.06$ & 0.10 \\
\hline Subcapsular Cataract (5) & $26.09 \pm 10.25$ & 0.15 \\
\hline
\end{tabular}

$\mathrm{N}$ : Number of samples. almost 4 times that of control lenses $(17.8 \pm 5.3)$. Although nuclear (NC) $(39.4 \pm 27.06, p=0.10)$ and subcapsular (SC) $(26.1 \pm 10.3, p=0.15)$ cataracts showed higher levels of iron but were not statistically significant.

\section{Evaluation of DNA damage as a measure of iron-in- duced oxidative stress}

The Comet assay (Figure 2A) was performed to find

Table 4: Assessment of DNA damage in LECs.

\begin{tabular}{|l|l|l|l|l|}
\hline & \multicolumn{4}{|c|}{ Parameters of DNA damage (Mean \pm S.E. $(\mathbf{p}))$} \\
\hline Type of LECs $(\mathbf{n})$ & Tail length $(\boldsymbol{\mu})$ & Tail DNA (\%) & Tail Moment (a.u) & OliveMoment (a.u) \\
\hline Control $(10)$ & $66.56 \pm 15.68$ & $40.03 \pm 11.40$ & $37.85 \pm 15.29$ & $26.97 \pm 8.12$ \\
\hline Cortical cataract $(8)$ & $79.59 \pm 21.31(p=0.0005)$ & $40.39 \pm 12.42(p=0.88)$ & $43.13 \pm 18.87(p=0.13)$ & $29.69 \pm 10.31(p=0.018)$ \\
\hline Nuclear cataract $(11)$ & $68.64 \pm 15.39(p=0.52)$ & $34.77 \pm 10.56(p=0.02)$ & $33.18 \pm 14.13(p=0.13)$ & $25.09 \pm 7.59(p=0.20)$ \\
\hline $\begin{array}{l}\text { Posterior subcapsular } \\
\text { cataract }(7)\end{array}$ & $68.98 \pm 19.09(p=0.49)$ & $37.12 \pm 11.99(p=0.23)$ & $34.69 \pm 17.13(p=0.34)$ & $26.48 \pm 9.09(p=0.70)$ \\
\hline
\end{tabular}

$\mathrm{N}$ : Number of samples, $\mathrm{p}$ : p-value.

Table 5: Assessment of DNA damage in $\mathrm{FHL} 124$ cell lines challenged with $\mathrm{FeCl}_{3}$.

\section{Parameters of DNA damage (Mean \pm S.E. (p))}

\begin{tabular}{|l|l|l|l|l|}
\hline Treatment group (n) & Tail length $(\boldsymbol{\mu})$ & Tail DNA (\%) & TailMoment (a.u.) & OliveMoment (a.u.) \\
\hline Control & $62.55 \pm 6.63$ & $27.39 \pm 5.14$ & $18.1 \pm 3.41$ & $18.88 \pm 2.86$ \\
\hline $150 \mu \mathrm{M}(3)$ & $68.93 \pm 2.95(p=0.29)$ & $24.1 \pm 3.91(p=0.69)$ & $17.93 \pm 1.86(p=0.98)$ & $20.64 \pm 1.24(p=0.61)$ \\
\hline $250 \mu \mathrm{M}(3)$ & $72.01 \pm 4.69(p=0.16)$ & $35.72 \pm 6.04(p=0.87)$ & $29.36 \pm 13.06(p=0.61)$ & $23.06 \pm 5.46(p=0.21)$ \\
\hline $500 \mu \mathrm{M}(3)$ & $80.71 \pm 8.63(p=0.01)$ & $44.01 \pm 18.02(p=0.05)$ & $36.87 \pm 17.33(p=0.02)$ & $27.41 \pm 6.72(p=0.02)$ \\
\hline
\end{tabular}

$\mathrm{N}$ : Number of replicates, a.u.: Arbitrary Units, p: p-value.

Table 6: Expression of iron regulatory genes in lenses.

\begin{tabular}{|c|c|c|c|c|c|c|c|c|c|}
\hline \multirow[b]{3}{*}{$\begin{array}{l}\text { Cataract } \\
\text { type (n) }\end{array}$} & \multicolumn{9}{|c|}{ Expression of target genes (fold change to control, mean \pm S.E. (p)) } \\
\hline & \multicolumn{3}{|c|}{ Iron Uptake and Import } & \multicolumn{3}{|c|}{ Iron Storage and Export } & \multicolumn{3}{|c|}{ Iron homeostasis } \\
\hline & NIRE-DMT1 & RE-DMT1 & TFR2 & FTH & FTL & FPN & IRP1 & RP2 & FBXL5 \\
\hline \multirow[t]{2}{*}{$\mathrm{CC}(34)$} & $0.80 \pm 0.14$ & $1.99 \pm 0.34$ & $0.12 \pm 0.02$ & $0.12 \pm 0.02$ & $0.23 \pm 0.04$ & $0.21 \pm 0.04$ & $1.05 \pm 0.18$ & $1.83 \pm 0.31$ & $1.83 \pm 0.31$ \\
\hline & $(p=0.83)$ & $(p=0.05)$ & $(p=0.06)$ & $(p=0.01)$ & $(p=0.06)$ & $(p=0.09)$ & $(p=0.96)$ & $(p=0.54)$ & $(p=0.09)$ \\
\hline \multirow[t]{2}{*}{ NC (48) } & $0.59 \pm 0.08$ & $1.51 \pm 0.11$ & $0.40 \pm 0.06$ & $0.30 \pm 0.09$ & $0.53 \pm 0.29$ & $0.48 \pm 0.09$ & $1.69 \pm 0.08$ & $0.86 \pm 0.04$ & $0.25 \pm 0.14$ \\
\hline & $(p=0.61)$ & $(p=0.58)$ & $(p=0.35)$ & $(p=0.14)$ & $(p=0.41)$ & $(p=0.31)$ & $(p=0.60)$ & $(p=0.87)$ & $(p=0.07)$ \\
\hline \multirow[t]{2}{*}{ PSC (24) } & $0.06 \pm 0.50$ & $0.71 \pm 0.07$ & $0.07 \pm 0.19$ & $0.13 \pm 0.27$ & $0.46 \pm 0.84$ & $0.23 \pm 0.27$ & $4.86 \pm 0.03$ & $1.03 \pm 0.00$ & $0.07 \pm 0.37$ \\
\hline & $(p=0.02)$ & $(p=0.75)$ & $(p=0.02)$ & $(p=0.03)$ & $(p=0.40)$ & $(p=0.11)$ & $(p=0.20)$ & $(p=0.98)$ & $(p=0.01)$ \\
\hline
\end{tabular}

CC: Cortical Cataract, NC: Nuclear Cataract, PSC: Posterior Subcapsular Cataract, $N=$ Number of samples, $p$ : $p$ value. 
the level of DNA damage in LECs of different types of cataract (Figure 2B and Table 4) and also in FHL124 cells treated with different concentrations of $\mathrm{FeCl}_{3}$ (Figure $2 \mathrm{C}$ and Table 5). The degree of DNA damage was assessed by four essential parameters such as tail length $(u)$, the percentage of DNA present in the tail, tail moment and
Olive moment (Figure 2A). The results showed a significant increase in tail length $(79.59 \pm 21.31$ vs. control, $66.56 \pm 15.68 ; p=0.0005)$, olive moment $(29.69 \pm 10.31$ vs. control, $26.97 \pm 8.12, p=0.018$ ), and an insignificant, increase in tail-moment $(43.13 \pm 18.87 \mathrm{vs}$. control, $37.85 \pm 15.29 ; p=0.13$ ) in CC. Nuclear cataract showed
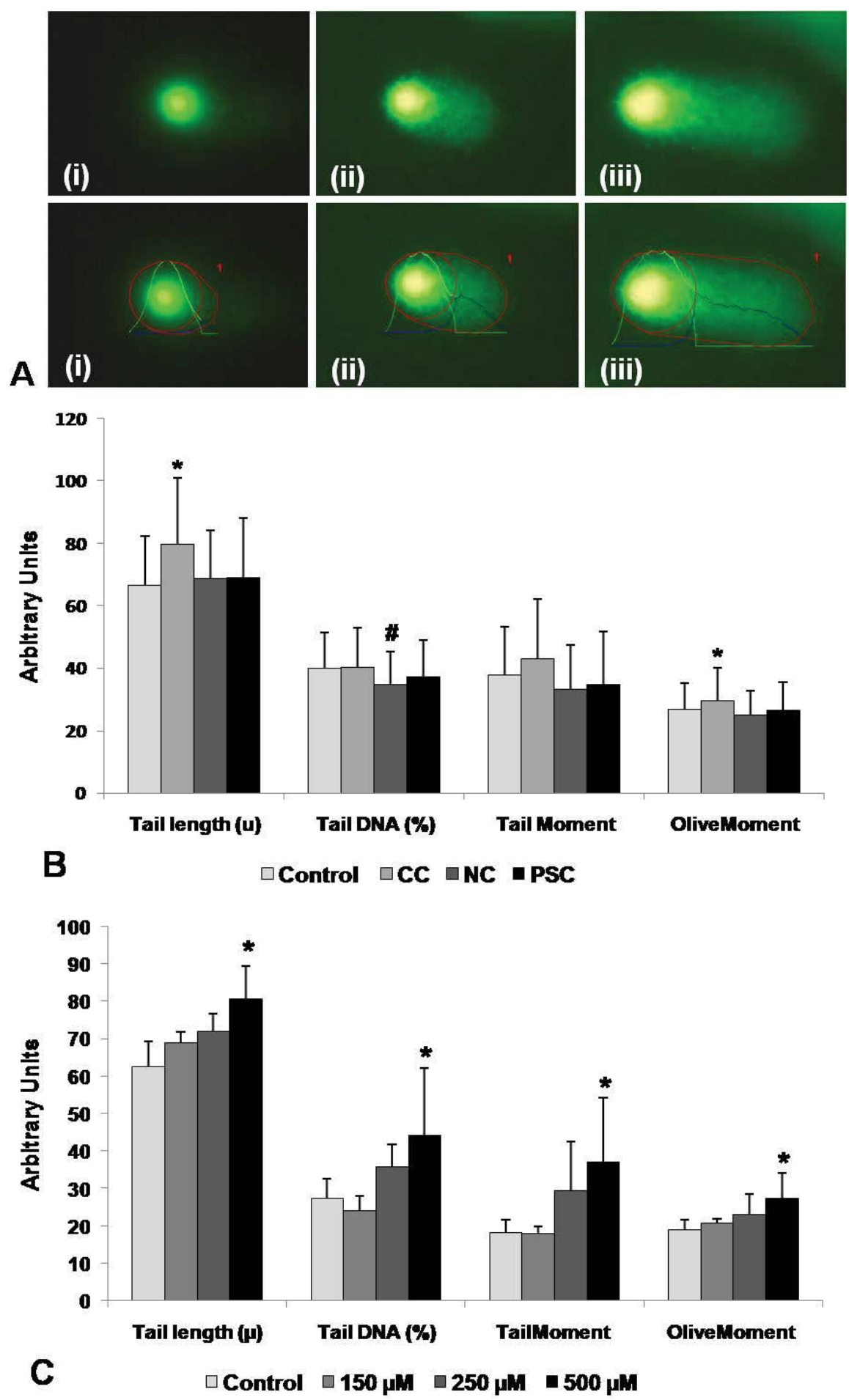

Figure 2: Assessment of DNA damage in human lens epithelial cells (LECs) and FHL124 cell lines.

A) Representative images of Comets showing different degree of DNA damage; i) no, ii) moderate and iii) higher. (B) Analysis of degree of DNA damage in lens epithelial cells of different types of lenses; Control, $(n=10)$, CC: cortical cataract, ( $n$ $=8)$, NC: nuclear cataract, $(n=11)$, PSC: posterior subcapsular cataract, $(n=7)$. (C) Analysis of degree of DNA damage in FHL124 cell lines treated with various concentrations $(\mu \mathrm{M})$ of $\mathrm{FeCl}_{3}$. Image analyses of various parameters such as \%DNA in head and tail, tail length (marked by blue line), tail moment and Olive moment was performed by Open Comet Software. Boundary mark indicates the area selected for the analyses of various parameters; red line indicates Comet length (head area, head diameter, tail area, tail length); green line indicates head DNA content in the comet; blue line indicates tail DNA content in the comet. "-indicates significant increase at $p<0.05$; ${ }^{*}$-indicates significant decrease at $p<0.05$. 
a significant decrease in tail DNA (\%) $(34.77 \pm 10.56$ vs. control, $40.03 \pm 11.40 ; p=0.02$ ) and PSC did not show any significant difference in any of the parameters tested (Figure 2B and Table 4).
To understand whether the presence of iron in lens epithelial cells plays role in DNA damage in vitro cell culture model using human fetal lens epithelial cell line (FHL124) was utilized. FHL124 cells treated with $\mathrm{FeCl}_{3}$
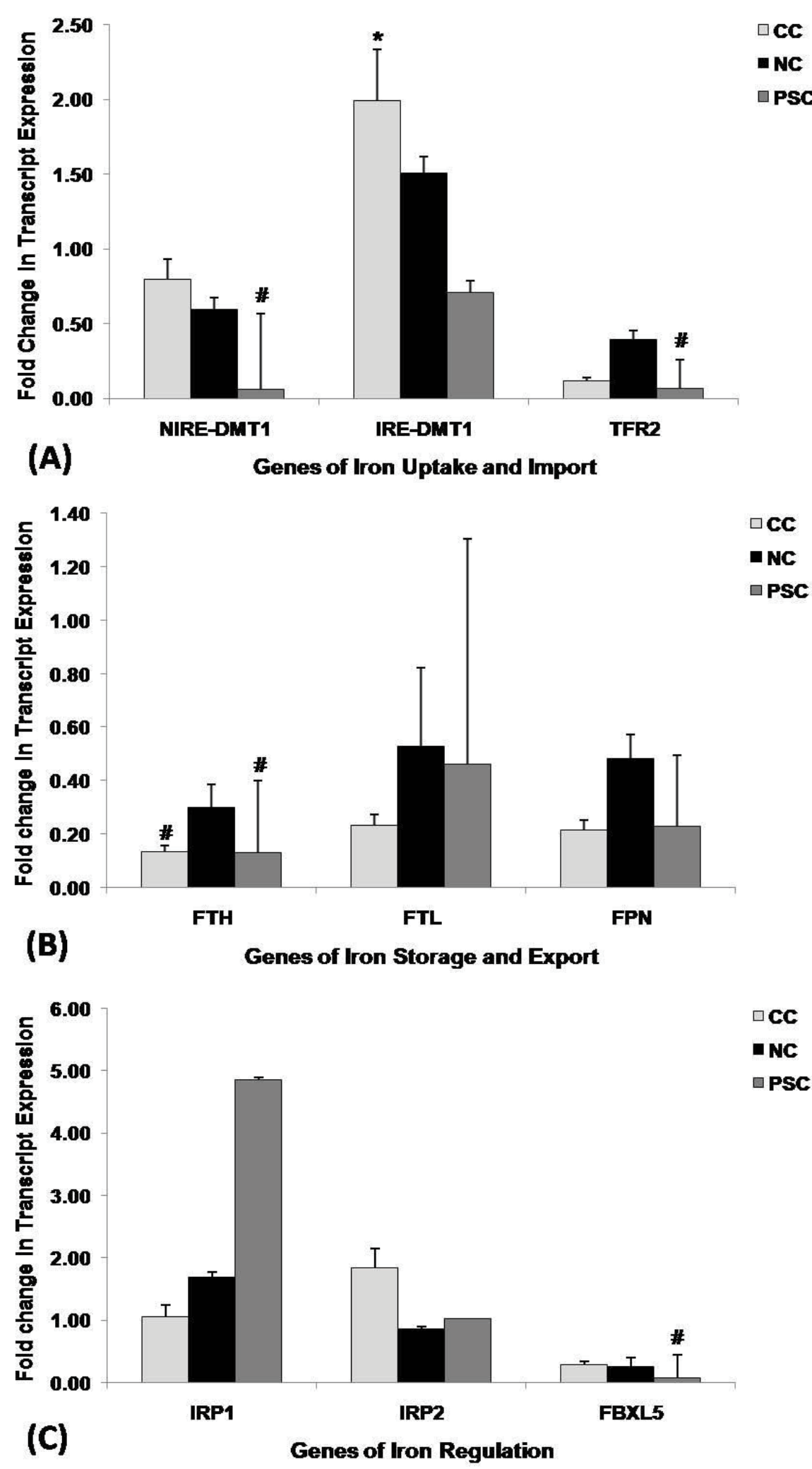

Figure 3: Transcript profiling of iron homeostasis genes in different types of lenses.

Comparison of level of transcript expression of; (A) Iron uptake and import genes, (B) Iron storage and export genes, (C) Iron regulatory genes between control $(n=25)$ and different types of cataract; CC: cortical cataract, $(n=34)$; NC: nuclear cataract, $(n=48)$, and PSC: posterior subcapsular cataract, $(n=25)$. Controls are subjects with clear lenses undergoing IOL implantation as a corrective procedure after trauma to lens by penetrative injuries or subjects with clear lenses undergoing myopic correction. Value of fold change in transcript expression is given as mean $\pm S$.E to control. "indicates significant increase at $p$ $<0.05$; \#indicates significant decrease at $\mathrm{p}<0.05$. 
Table 7: Expression of iron regulatory genes in FHL124 cells upon iron challenge.

\begin{tabular}{|c|c|c|c|c|c|c|c|c|c|}
\hline \multirow[b]{3}{*}{$\begin{array}{l}\text { Treatment } \\
\text { Group (n) }\end{array}$} & \multicolumn{9}{|c|}{ Expression of target genes (fold change to control, mean \pm S.E. (p)) } \\
\hline & \multicolumn{3}{|c|}{ Iron Uptake and Import } & \multicolumn{3}{|c|}{ Iron Storage and Export } & \multicolumn{3}{|c|}{ Iron homeostasis } \\
\hline & NIRE-DMT1 & RE-DMT1 & TFR2 & FTH & FTL & FPN & IRP1 & RP2 & FBXL5 \\
\hline \multirow[t]{2}{*}{$150 \mu \mathrm{M}(3)$} & $1.89 \pm 0.07$ & $3.56 \pm 0.95$ & $0.58 \pm 0.18$ & $0.72 \pm 1.02$ & $0.84 \pm 1.07$ & $1.80 \pm 0.74$ & $0.51 \pm 0.60$ & $0.63 \pm 2.33$ & $1.30 \pm 0.96$ \\
\hline & $(p=0.04)$ & $(p=0.01)$ & $(p=0.28)$ & $(p=0.01)$ & $(p=0.31)$ & $(p=0.20)$ & $(p=0.38)$ & $(p=0.69)$ & $(p=0.13)$ \\
\hline \multirow[t]{2}{*}{$250 \mu \mathrm{M}(3)$} & $2.66 \pm 0.06$ & $1.60 \pm 1.00$ & $0.37 \pm 0.08$ & $0.73 \pm 1.05$ & $1.09 \pm 0.99$ & $3.56 \pm 1.03$ & $0.99 \pm 0.57$ & $2.46 \pm 1.03$ & $2.67 \pm 1.06$ \\
\hline & $(p=0.04)$ & $(p=0.18)$ & $(p=0.42)$ & $(p=0.02)$ & $(p=0.40)$ & $(p=0.08)$ & $(p=0.99)$ & $(p=0.06)$ & $(p=0.00)$ \\
\hline \multirow[t]{2}{*}{$500 \mu \mathrm{M}(3)$} & $4.96 \pm 0.08$ & $0.43 \pm 0.09$ & $0.28 \pm 0.02$ & $1.83 \pm 1.02$ & $2.43 \pm 1.02$ & $7.47 \pm 0.90$ & $1.48 \pm 0.53$ & $3.57 \pm 1.74$ & $3.10 \pm 0.98$ \\
\hline & $(p=0.03)$ & $(p=0.02)$ & $(p=0.22)$ & $(p=0.0005)$ & $(p=0.0013)$ & $(p=0.012)$ & $(p=0.59)$ & $(p=0.19)$ & $(p=0.00)$ \\
\hline
\end{tabular}

$\mathrm{N}$ : Number of replicates, $\mathrm{p}=\mathrm{p}$-value.

revealed a significant increase in tail length $(p=0.01)$, percentage tail DNA $(p=0.05)$, tail-moment $(p=0.02)$ and olive-moment $(p=0.02)$ at higher concentration (500 $\mu \mathrm{M}$ ) of $\mathrm{FeCl}_{3}$, a concentration equal to that of lenticular iron level in cortical cataract (Figure 2C and Table 5).

\section{Differential expression of iron homeostasis genes in different types of cataract lenses}

The quantitative real-time PCR (QRT-PCR) analysis was carried out for genes responsible for iron uptake and import (i.e. DMT1 and TFR2), storage (i.e. FTH and $F T L$ ), export (i.e. FPN) and homeostasis (i.e. FBXL5, IRP1 and IRP2) in lenses. The level of transcript expression of these genes was compared between clear and different types of cataract (Figure 3 and Table 6).

Cortical cataract (CC) revealed a significant up-regulation of IRE-DMT1 (fold change to control, $1.99 \pm 0.34 ; p$ $=0.046$ ) (Figure $3 \mathrm{~A}$ and Table 6) and down-regulation of FTH (fold change to control, $0.13 \pm 0.02 ; p=0.01$ ) (Figure 3B and Table 6) gene transcripts. However, although statistically insignificant, it also revealed a down-regulation of FTL (fold change to control, $0.23 \pm 0.04 ; p=0.06$ ), FPN (fold change to control, $0.21 \pm 0.04 ; p=0.09$ ) (Figure $3 \mathrm{~B}$ and Table 6) and FBXL5 (fold change to control, $0.28 \pm$ $0.05 ; p=0.09$ ) (Figure $3 C$ and Table 6 ) gene transcripts.

Nuclear cataract (NC) did not show any significant changes in any of the genes tested. However, although statistically insignificant, NC exhibited an up-regulation of IRE-DMT1 (fold change to control, $1.51 \pm 0.11 ; p=$ 0.058 ) (Figure $3 A$ and Table 6 ) and down-regulation of FBXL5 (fold change to control, $0.25 \pm 0.14 ; p=0.07$ ) (Figure $3 C$ and Table 6 ) gene transcripts.

Posterior subcapsular cataract (PSC) showed a significant down-regulation of NIRE-DMT1 (fold change to control, $0.06 \pm 0.50 ; p=0.02$ ), TFR2 (fold change to control, $0.07 \pm 0.19 ; p=0.02$ ) (Figure $3 \mathrm{~A}$ and Table 6), FTH (fold change to control, $0.23 \pm 0.27 ; p=0.03$ ) and $F B X L 5$ (fold change to control, $0.07 \pm 0.37 ; p=0.01$ ) (Figure $3 C$ and Table 6) gene transcripts.

In vitro analysis revealed a conventional coordinated regulation of genes responsible for iron metabolism

In vitro validation on effect of challenge with iron supplementation on expression of iron regulatory genes was performed using human lens epithelial cells line (FHL124). QRT-PCR analyses of FHL124 cells challenged with $\mathrm{FeCl}_{3}$ revealed a dose-dependent increase in gene transcripts of NIRE-DMT1 (Figure 4A), FTH, FPN (Figure $4 B$ ), and FBXL5 (Figure 4C and Table 7) and a dose dependent decrease in IRE-DMT1 (Figure 4A) gene transcripts. The level of $F T L$ gene transcript is found to be significantly up-regulated at $500 \mu \mathrm{M} \mathrm{FeCl}_{3}$ supplementation (Figure 4B and Table 7), while no significant difference in level of expression was observed with gene transcripts of TFR2, IRP1 and IRP2 (Figure 4A, Figure 4C and Table 7).

\section{Discussion}

Oxidative stress mediated by redox-active transition elements is one of the major pathways in cataractogenesis $[51,52]$. It was suggested that when a tissue's storage capacity is persistently exceeded, un-sequestered iron catalysis the formation of reactive oxygen species via Fenton reaction, which leads not only to irreversible tissue damage with clinical manifestations but also to a higher risk of age-related diseases [34,53,54]. The present study reveals an increased level of iron in cataractous lenses, especially in cortical cataracts (CC) and a plethora of studies support the current finding [52,54,55-63]. As age-related cataracts, in part, were a result of oxidative modification of lens proteins, we presume that the excess iron could be one of the factors responsible for oxidative modifications and subsequent opacification of lenses, especially in cortical cataracts.

To delineate the potential role of iron in the process of oxidative damage, we performed COMET assay for assessing oxidative stress by means of degree of DNA damage, in both human lens epithelial cells (hLECs) and cell lines (Fetal Human Lens epithelial cell line 124). The use of LECs for detecting oxidative DNA damage was applied in several studies [64-66] as epithelial cells were suggested to be better bio-matrices for analyzing Comet assay [67]. In the present study, highest level of DNA damage was observed in LECS of CC, similar to the results obtained by Sorte and co-workers [64], and at a higher concentration (500 $\mu \mathrm{M})$ of iron supplementation in FHL124 cell lines. These observations highlight a potential role of free iron in generation of oxidative stress and subsequent oxidative damage to macromolecules in cells. 

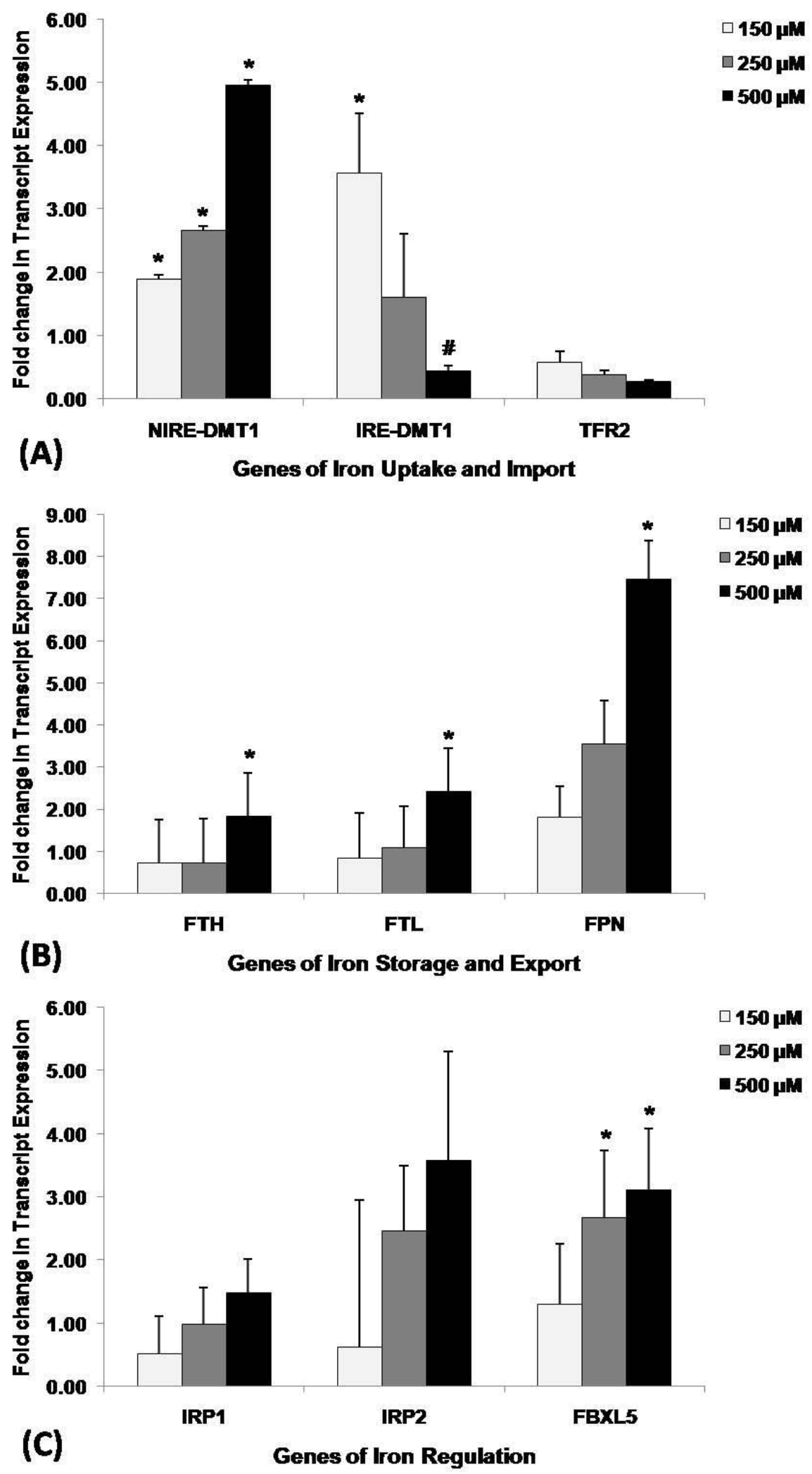

Figure 4: Transcript expression of iron homeostasis genes in FHL124 cell lines upon exogenous iron supplementation.

Comparison of level of transcript expression of; (A) Iron uptake and import genes, (B) Iron storage and export genes, (C) Iron regulatory genes between control $(n=3)$ and different types of treatment groups $(150,250$ and $500 \mu M)$. Value of fold change in transcript expression is given as mean \pm S.E to control. "indicates significant increase at $p<0.05$; \#indicates significant decrease at $p<0.05$.

To understand the possible mechanism of iron-overload in lens tissues, we performed transcript profiling and expression status of genes responsible for iron homeostasis (i.e. DMT1, TFR2, FTH, FTL, FPN, IRP1, IRP2 
and $F B X L 5$ ) in human lenses. The lenses of cortical cataract exhibited an elevated level of IRE-form of DMT1 (IRE-DMT1), and a diminished level of FTH gene transcripts, while lenses of subcapsular cataracts showed a diminished level of non-IRE form of DMT1 (NIRE-DMT1), TFR2, FTH and FBXL5 gene transcripts. The uptake of iron inside the cell is mediated by two specific transporters namely divalent metal ion transporter 1 (DMT1) and transferrin receptor (TFR). DMT1 is a single transmembrane transporter and is also located in transferrin-cycle endosomes [68]. DMT1 is encoded by the gene, SLC11A2, and expressed in four major isoforms: $1 \mathrm{~A} /+$ IRE, $1 \mathrm{~A} /$-IRE, $1 \mathrm{~B} /+\mathrm{IRE}$, and $1 \mathrm{~B} /$-IRE. It was found that IRE-DMT1 is expressed predominantly by epithelial cell lines, whereas NIRE-DMT1 is expressed by blood cell lines [69]. Nevertheless, these two isoforms, IRE- and NIRE-DMT1, are known to be of physiological importance in the maintenance of cellular iron homeostasis by bringing iron into cells. A few reports are available to confirm the occurrence of TFR in lenses and other ocular tissues $[70,71]$ and the presence of transferrin in the aqueous and vitreous humor $[71,72]$ suggesting the existence of transferrin receptor-mediated iron-uptake in LECs [73]. However, the existence and localization, or expression of DMT1 in the lens is yet undetermined [74]. This report is the first of its kind showing the expression of both the form of DMT1 in human lens tissues. To confirm the presence of full length DMT1 gene transcripts we performed polymerase chain reaction using gene specific primers (sequences can be availed upon request) and to confirm the sequence homology we performed bidirectional Sanger's sequencing. The full length DMT1 transcript sequence has shown $100 \%$ homology to isoform 2 (i.e. NIRE DMT1) and has been submitted to GenBank (accession number KT455015). The presence of NIRE-DMT1 transcripts in lenses indicates a possible role of DMT1 in modulating iron translocation in response to cellular demands as in other tissues. Mutations in the IRE of L-ferritin (FTL) mRNA are reported to abrogate IRP binding, promote accumulation of non-functional L-ferritin homopolymers in the lens, and result in hereditary hyperferritinemia-cataract syndrome (HHCS) [75]. As the mRNA level of FTL did not change significantly in any type of cataract, the role of L-ferritins in the causation of cataract could not be established in the present study. Further none of the selected cataract cases in the present study are reported to have HHCS.

The results of an in vitro analysis indicate that when the threshold level of intracellular iron concentration is reached, the cell starts synthesizing proteins responsible for sequestration and exportation, while abrogating the synthesis of proteins responsible for iron uptake. It was reported that when the cytosolic iron concentration becomes high, IRPs abrogate the translation of DMT1 and induces the synthesis of ferritin storage proteins [76]. This pattern, at least at mRNA level, was observed in the present study when the FHL124 cells were treated with increasing concentration of iron. Therefore, it is evident from the in vitro analysis that human lens epithelial cells exhibit a conventional coordinated regulation of genes responsible for iron metabolism when they are challenged with exogenous supplementation of iron.

From the current findings, it could be hypothesized that the increased inflow of iron (owing to increased expression of DMT1 transcripts) and compromised lens iron storage capacity (owing to diminished expression of FTH transcripts) in cortical cataract might resulted in excess of un-sequested iron in the cell. This could have led to lenticular opacification due to increased oxidative damage to macromolecules. However, the present study has a few limitations to conclude the causal association of current findings with the cataractogenesis. First, the unavailability of sufficient donor eyes and/or control lenses for determination of the lenticular iron; second, selection of COMET assay alone for determining oxidative stress; third, absence of protein data on expression of iron homeostasis genes. This is a preliminary pilot study to correlate the level of iron and transcript expression of iron regulatory genes with different types of cataract. However, a future study shall be conducted to unravel the correlation between level of lenticular iron and expression status of iron regulatory genes at each grade of specific cataract type including the protein expression profiles of all iron homeostasis genes with large sample size.

\section{Conclusion}

We highlight a potential role of iron in oxidative DNA damage and differential expression of iron homeostasis genes in cataracts, especially in cortical cataracts. If these facts are well established in large cohorts of cataract population, it could provide an avenue to formulate therapeutics to prevent the formation of iron-mediated cataractogenesis. The up-regulation of IRE-DMT1 in lenses of cortical cataract further warrants the necessity of a systemic study involving physiological, environmental, and genetic factors to understand the exact underlying mechanisms.

\section{Acknowledgements}

This work was partly supported by a grant to S.R.K. from the Indian Council of Medical Research, New Delhi (F.N.5/4/6/2012-RMC). The funding agency did not have any role in study design, sample collection, analysis, interpretation of data, writing the manuscript and decision to submit the paper for publication. We thank Geereddy Bhanuprakash Reddy and Rajendran Anandhan, National Institute of Nutrition, Hyderabad for atomic absorption spectrophotometry analysis, Bijay Kumar Behera, ICAR-Central Inland Fisheries Research Institute, Kolkata for real-time PCR facilities and Kamalakannan Dhati Radhakrishnan, Thiagarajar College, Madurai for his contribution in manuscript preparation. The authors do not have any conflict of interest. 


\section{References}

1. Beebe DC (2008) Maintaining transparency: A review of the developmental physiology and pathophysiologyof two avascular tissues. Semin Cell Dev Biol 19: 125-133.

2. Dische Z, Zil H (1951) Studies on the oxidation of cysteine to cystine in lens proteins during cataract formation. Am J Ophthalmol 34: 104-113.

3. Garner WH, Garner MH, Spector A (1983) H2O2-induced uncoupling of bovine lens $\mathrm{Na}+\mathrm{K}+-\mathrm{ATP}$ ase. Proc Natl Acad Sci U S A 80: 2044-2048.

4. Kleiman NJ, Spector A (1993) DNA single strand breaks in human lens epithelial cells from patients with cataract. Curr Eye Res 12: 423-431.

5. Augusteyn RC (1981) Protein modifications in cataract: possible oxidative mechanisms. In: Duncan G, Mechanisms of cataract formation in the human lens. Academic Press, London, 71-115.

6. Harding JJ, Crabbe MJ (1984) The lens: development, proteins, metabolism and cataract. In: Davson $\mathrm{H}$, The Eye. Vol 1B, Academic Press, Orlando, Florida, USA.

7. Harding JJ (1992) The physiology, biochemistry, pathogenesis and the epidemiology of cataracts. Current Opinion in Ophthalmology 3: 3-12.

8. Spector A (1995) Oxidative stress-induced cataract: mechanism of action. FASEB J 9: 1173-1182.

9. Taylor VL, al-Ghoul KJ, Lane CW, Davis VA, Kuszak JR, et al. (1996) Morphology of the normal human lens. Invest Ophthalmol Vis Sci 37: 1396-1410.

10. Rockville (1993) Cataract Management Guideline Panel. Clinical Practice Guideline, Number 4, U.S. Department of Health and Human Services, Public Health Service, Agency for Health Care Policy and Research. Cataract in adults: Management of functional impairment. 5-28.

11. Foster A (2001) Cataract and "Vision 2020-the right to sight" initiative. Br J Ophthalmol 85: 635-637.

12. Report WHO (1997) Blindness and Visual Disability; Part II of VII: major causes worldwide. Geneva, Switzerland: World Health Organization.

13. Khairallah $M$, Kahloun $R$, Bourne $R$, Limburg $H$, Flaxman SR, et al. (2015) Number of People Blind or Visually Impaired by Cataract Worldwide and in World Regions, 1990 to 2010. Invest Ophthalmol Vis Sci 56: 6762-6769.

14. Ponka $P$, Lok CN (1999) The transferrin receptor: role in health and disease. Int J Biochem Cell Biol 31: 1111-1137.

15. Rouault TA (2001) Systemic iron metabolism: a review and implications for brain iron metabolism. Pediatr Neurol 25: 130-137.

16. Herbison CE, Thorstensen K, Chua AC, Graham RM, Leedman P, et al. (2009) The role of transferrin receptor 1 and 2 in transferrin-bound iron uptake in human hepatoma cells. Am J Physiol Cell Physiol 297: 1567-1575.

17. Anderson CP, Shen M, Eisenstein RS, Leibold EA (2012) Mammalian iron metabolism and its control by iron regulatory proteins. Biochim Biophys Acta 1823: 1468-1483.

18. Rouault TA (2009) Cell biology. An ancient gauge for iron. Science 326: 676-677.

19. Vashisht AA, Zumbrennen KB, Huang X, Powers DN, Durazo A, et al. (2009) Control of iron homeostasis by an iron-regulated ubiquitin ligase. Science 326: 718-721.
20. Salahudeen AA, Thompson JW, Ruiz JC, Ma HW, Kinch LN, et al. (2009) An E3 ligase possessing an iron-responsive hemerythrin domain is a regulator of iron homeostasis. Science 326: 722-726.

21. Ruiz JC, Walker SD, Anderson SA, Eisenstein RS, Bruick RK (2013) F-box and leucine-rich repeat protein 5 (FBXL5) is required for maintenance of cellular and systemic iron homeostasis. J Biol Chem 288: 552-560.

22. Chollangi S, Thompson JW, Ruiz JC, Gardner KH, Bruick RK (2012) Hemerythrin-like domain within F-box and leucine-rich repeat protein 5 (FBXL5) communicates cellular iron and oxygen availability by distinct mechanisms. J Biol Chem 287: 23710-23717.

23. Thompson JW, Bruick RK (2012) Protein degradation and iron homeostasis. Biochim Biophys Acta 1823: 1484-1490.

24. Anderson GJ (2007) Mechanisms of iron loading and toxicity. Am J Hematol 82: 1128-1131.

25. He X, Hahn P, lacovelli J, Wong R, King C, et al. (2007) Iron homeostasis and toxicity in retinal degeneration. Prog Retin Eye Res 26: 649-673.

26. Halliwell B, Gutteridge JM (1990) Role of free radicals and catalytic metal ions in human disease: an overview. Methods Enzymol 186: 1-85.

27. Fleming RE, Ponka P (2012) Iron overload in human disease. N Engl J Med 366: 348-359.

28. Madsen E, Gitlin JD (2007) Copper and iron disorders of the brain. Annu Rev Neurosci 30: 317-337.

29. Hope-Ross M, Mahon GJ, Johnston PB (1993) Ocular siderosis. Eye (Lond) 7: 419-425.

30. O'Duffy D, Salmon JF (1999) Siderosis bulbi resulting from an intralenticular foreign body. Am J Ophthalmol 127: 218-219.

31. Lee W, Park SY, Park TK, Kim HK, Ohn YH (2007) Mature cataract and lens-induced glaucoma associated with an asymptomatic intralenticular foreign body. J Cataract Refract Surg 33: 550-552.

32. Wu TT, Kung YH, Sheu SJ, Yang CA (2009) Lens siderosis resulting from a tiny missed intralenticular foreign body. $J$ Chin Med Assoc 72: 42-44.

33. Siantar RG, Agrawal R, Heng LW, Ho BC (2013) Histopathologically proven siderotic cataract with disintegrated intralenticular foreign body. Indian J Ophthalmol 61: 30-32.

34. Loh A, Hadziahmetovic M, Dunaief JL (2009) Iron homeostasis and eye disease. Biochim Biophys Acta 1790: 637649.

35. Goralska M, Ferrell J, Harned J, Lall M, Nagar S, et al. (2009) Iron metabolism in the eye: a review. Exp Eye Res 88: $204-215$

36. Brown NAP, Bron AJ (1996) A clinical manual of cataract diagnosis. Ch.3. Butterworth-Heinemann Ltd., Oxford: Lens disorders: 17-31.

37. Wong RW, Richa DC, Hahn P, Green WR, Dunaief JL (2007) Iron toxicity as a potential factor in AMD. Retina 27: 997-1003.

38. Ciudin A, Hernández C, Simó R (2010) Iron overload in diabetic retinopathy: a cause or a consequence of impaired mechanisms? Exp Diabetes Res 2010.

39. Sulochana KN, Coral K, Punitham R, Sharma T, Kasinatham N, et al. (2004) Trace elements iron, copper and zinc in vitreous of patients with various vitroretinal disease. Indian J Ophthalmol 52: 145-148. 
40. Chylack LT Jr., Wolfe JK, Singer DM, Leske MC, Bullimore MA, et al. (1993) The Lens Opacities Classification System III. The Longitudinal Study of Cataract Study Group. Arch Ophthalmol 111: 831-836.

41. Rajkumar $S$, Vasavada AR, Praveen MR, Ananthan R, Reddy $\mathrm{GB}$, et al. (2013) Exploration of molecular factors responsible for impairment of superoxide dismutase isoforms in human cataractous lenses. Invest Ophthalmol Vis Sci 54: 6224-6233.

42. Reddan JR, Lindemann CB, Hitt AL, Bagchi M, Raphtis EM, et al. (1999) Generation of two non-transfected human lens epithelial cell lines [ARVO Abstract]. Invest. Ophthalmol. Vis. Sci. 40 S970. Abstract nr 5110.

43. Ganatra DA, Rajkumar S, Patel AR, Gajjar DU, Johar K, et al. (2015) Association of histone acetylation at the ACTA2 promoter region with epithelial mesenchymal transition of lens epithelial cells. Eye (Lond) 29: 828-838.

44. Wormstone IM, Tamiya S, Eldred JA, Lazaridis K, Chantry A, et al. (2004) Characterisation of TGF-beta2 signalling and function in a human lens cell line. Exp Eye Res 78: 705-714.

45. Pfaffl MW, Morgan GW, Dempfle L (2000) Relative Expression Software Tool (REST) for group-wise comparison and statistical analysis of relative expression results in real-time PCR. Nucleic Acid Res 30: e36.

46. Singh NP (2000) A Simple Method for Accurate Estimation of Apoptotic Cells. Exp Cell Res 256: 328-337.

47. Rajkumar S (2011) Genetic and Biochemical Modulation of superoxide dismutase (SOD) in human senile cataracts. In: PhD Thesis, Manipal University, India, 64.

48. Nanavaty MA, Johar K, Sivasankaran MA, Vasavada AR, Praveen MR, et al. (2006) Effect of trypan blue staining on the density and viability of lens epithelial cells in white cataract. J Cataract Refract Surg 32: 1483-1488.

49. Singh NP, McCoy MT, Tice RR, Schneider E (1988) A simple technique for quantitation of low levels of DNA damage in individual cells. Exp Cell Res 175: 184-191.

50. Gyori BM, Venkatachalam G, Thiagarajan PS, Hsu D, Clement MV (2014) OpenComet: an automated tool for comet assay image analysis. Redox Biol 2: 457-465.

51. Garner B, Davies MJ, Truscott RJ (2000) Formation of hydroxyl radicals in the human lens is related to the severity of nuclear cataract. Exp Eye Res 70: 81-88.

52. Garner B, Roberg K, Qian M, Eaton JW, Truscott RJ (2000) Distribution of ferritin and redox-active transition metals in normal and cataractous human lenses. Exp Eye Res 71: 599-607.

53. Aposkitis $C$ (1970) The role of trace elements in the appearance of senile cataracts. Ann Ocul (Paris) 203: 925-930.

54. Garland D (1990) Role of site-specific, metal-catalyzed oxidation in lens aging and cataract: a hypothesis. Exp Eye Res 50: 677-682.

55. Cioli S, Mazzilli G (1970) Determination of iron content in human and animal lens and cornea and in human cataractous lens. Ann Ottalmol Clin Ocul 96: 297-302.

56. Swanson AA, Truesdale AW (1971) Elemental analysis in normal and cataractous human lens tissue. Biochem Biophys Res Commun 45: 1488-1496.

57. Eckhert CD (1983) Elemental concentrations in ocular tissues of various species. Exp Eye Res 37: 639-647.

58. Cernea P, Tanasescu D, Saninoiu M, Petria I (1985) Determination of the iron content of the normal lens and the cataracted lens. Bull Mem Soc Fr Ophtalmol 96: 311-313.
59. Cekiç O, Bardak Y, Totan Y, Kavakli S, Akyol O, et al. (1999) Nickel, chromium, manganese iron and aluminium levels in human cataractous and normal lenses. Ophthalmic Res 31: 332-336.

60. Dawczynski J, Blum M, Winnefeld K, Strobel J (2002) Increased content of zinc and iron in human cataractous lenses. Biol Trace Elem Res 90: 15-23.

61. Aydin E, Cumurcu T, Ozugurlu F, Ozyurt H, Sahinoglu S, et al. (2005) Levels of iron, zinc, and copper in aqueous humor, lens, and serum in nondiabetic and diabetic patients: their relation to cataract. Biol Trace Elem Res 108: 33-41.

62. Cumurcu T, Mendil D, Etikan I (2006) Levels of zinc, iron, and copper in patients with pseudoexfoliative cataract. Eur J Ophthalmol 16: 548-553.

63. Konz I, Fernández $B$, Fernández $M L$, Pereiro $R$, González-Iglesias H, et al. (2014) Quantitative bioimaging of trace elements in the human lens by LA-ICP-MS. Anal Bioanal Chem 406: 2343-2348.

64. Sorte K, Sune P, Bhake A, Shivkumar VB, Gangane N, et al. (2011) Quantitative assessment of DNA damage directly in lens epithelial cells from senile cataract patients. Mol Vis 17: 1-6.

65. Øsnes-Ringen O, Azqueta AO, Moe MC, Zetterström C, Røger M, et al. (2013) DNA damage in lens epithelium of cataract patients in vivo and ex vivo. Acta Ophthalmol 91: 652-656.

66. Zhang J, Wu J, Yang L, Zhu R, Yang M, et al. (2014) DNA damage in lens epithelial cells and peripheral lymphocytes from age-related cataract patients. Ophthalmic Res 51: 124-128.

67. Rojas E, Lorenzo Y, Haug K, Nicolaissen B, Valverde M (2014) Epithelial cells as alternative human biomatrices for comet assay. Front Genet 5: 386.

68. Gunshin H, Mackenzie B, Berger UV, Gunshin Y, Romero MF, et al. (1997) Cloning and characterization of a mammalian proton-coupled metal-iron transporter. Nature 288: 482-488.

69. Tabuchi M, Tanaka N, Nishida-Kitayama J, Ohno H, Kishi F (2002) Alternative splicing regulates the subcellular localization of divalent metal transporter 1 isoforms. Mol Biol Cell 13: 4371-4387.

70. McGahan MC, Harned J, Grimes AM, Fleisher LN (1994) Regulation of ferritin levels in cultured lens epithelial cells. Exp Eye Res 59: 551-555.

71. McGahan MC, Harned J, Goralska M, Sherry B, Fleisher LN (1995) Transferrin secretion by lens epithelial cells in culture. Exp Eye Res 60: 667-673.

72. Laicine EM, Haddad A (1994) Transferrin, one of the major vitreous proteins, is produced within the eye. Exp Eye Res 59: 441-445.

73. Harned J, Fliesher LN, McGahan MC (2006) Lens epithelial cells synthesize and secrete ceruloplasmin: Effects of ceruloplasmin and transferrin on iron efflux and intracellular iron dynamics. Exp Eye Res 83: 721-727.

74. García-Castiñeiras S (2010) Iron, the retina and the lens: a focused review. Exp Eye Res 90: 664-678.

75. Levi S, Girelli D, Perrone F, Pasti M, Beaumont C, et al. (1998) Analysis of ferritins in lymphoblastoid cell lines and in the lens of subjects with hereditary hyperferritinemia cataract syndrome. Blood 91: 4180-4187.

76. Thomson AM, Rogers JT, Leedman PJ (1999) Iron-regulatory proteins, iron-responsive elements and ferritin mRNA translation. Int J Biochem Cell Biol 31: 1139-1152. 